\title{
Maria Velho da Costa: celebrações
}

Tota pulchra es, Maria! Et macula non est in te!

Esta invocação encerra a carta que escrevo a Maria Velho da Costa no dia 22 de Maio de 2020 e, às 11h., confio ao balcão postal: "Chega em três ou quatro dias", promete a funcionária. Gratificada sinto-me por ter satisfeito a vontade de conversar com a minha escritora. Ela, afinal, ficaria sabendo as novidades a que seu telefone recusava dar voz. Ainda no domingo da Missa in Albis, eu insistira e depois. Precisava contar a Maria Velho do mais recente curso que eu lecionara a alunos de Pós-Graduação da Pontifícia Universidade Católica do Rio Grande do Sul, e que o iniciara com o texto "Elas" de Cravo, a causar emotividade, mesmo a instaurar atmosfera... poética! Essa que nós, professores de Literatura, tanto almejamos e valorizamos. Queria informar à Maria dos versos de Armando Silva Carvalho, copiados por Mário Quintana, à página setecentos e noventa e seis de sua Poesia Completa. Uma surpresa! E mais: reforçar o gozo estético pela sua criação lúdico-verbal e repetir-lhe o encantamento vivido a cada leitura de "A Velada" ${ }_{1}$ de O Lugar Comum e de "Elvira" de Casas Pardas. Tanto assim que, na última página do romance, exulto, a lápis, o louvor com o qual me despeço: "Tota pulchra es, Maria! Et macula non est in te!"

A carta estava a caminho e Maria Velho da Costa partia para outra dimensão. Era o dia 23 de maio de 2020.

Mas o Português é a minha voz e o meu corpo,

o que dele não morre com a minha morte. ${ }^{2}$

Herança outorgada! Tesouro aquinhoado! Celebração da Língua Portuguesa e da humanidade! De O Lugar Comum a Myra alinham-se destinos formulados em elevado nível expressivo.

A começar por "Exílio Menor", mentes meninas sucedem-se. É Lurdes "subindo com esforço dois degraus de seguida"; Maina Mendes "em cima da cadeira pesada de arrastar"; Lucinha ${ }^{5}$ levando "os dedos à mancha rosada que é a cara de sua mãe"; Elisa ${ }^{6}$ "pequena diante de uma carteira das que levantam a tampa"; Elvira7 "pequena e descalça por um carreiro na bouça"; Mary "com a grande boneca ao colo"; Raquel9 escondendo "a cabeça para o que não entendia" e $\mathrm{Myra}^{10}$ fugindo "outra vez para muito longe". As Mamães surgem com a jovem de "O Furto" ${ }_{11}$ contando "apenas ao seu filho a mágoa de não haver estado com ele desde o início"; Maria Eduarda12 em gestação a "Glóbulos e orbes de luz branca perfazem re- 
voluções fulgurantes", assim como Elvira ${ }^{13}$ "ao princípio era a esfera. opaca e quente mole". Para três jovens constroem-se habitações. São as Casas Pardas destinadas a Elisa, Elvira e Mary, havendo espaço de reunião como teatro. Organizam-se as moradas em capítulos com designações: Casas de Elisa: I - Vaga; II - Os Trabalhos de Casa: Pote Podre; A Terça casa; IV - Angelus; V - Língua. Casas de Elvira: I - Epifania; II - Lacrimosa; A Terça casa; IV - Stella; V - Atrium. Casas de Mary: I - Acquosa; II - Gávea; A Terça casa; IV - Cápsula; V - Declinação.

O narrador onisciente abre essas residências com detalhes sugestivos. A casa "Vaga" de Elisa atende com vivacidade: "Que lindo dia, que lindo dia, margaridinhas de olho de oiro palmeirando mínimas os canteiros na berma da rua". Já a casa "Epifania" de Elvira indigita sua proprietária: "Tu vais por uma vinha afora, que é vinha grada por todos os lados"; enquanto a casa "Acquosa" é direta na nomeação: "Mary caminha a custo um solo ressequidíssimo à sua volta, até perder de vista." Índices significativos antecipam contextos. Aguardam informes do narrador e das personagens.

Elisa tem a casa "Vaga", e vai preencher de "Trabalhos" até "Angelus" anunciar o nascimento de "Língua". O Anjo sabe que "o Pentecostes nasce é para todos. É a língua da alma". Reforça-se a escritora. Concretiza-se um destino. Para Elisa "é do contar histórias que não prescinde e embora saiba que só saberá de todas essas indagações escrevendo-as".

"Acquosa" Mary chora e esvai-se a chorar, indo à "Gávea", ingerindo a "Cápsula" para seu "grande sono" e sua "Declinação".

"Epifania" ilumina o caminho de Elvira. E, à ameaça de "Lacrimosa" toldar o sentido, sobrepõe-se "Stella", repondo o brilho e conduzindo Elvira para o "Atrium", portal aberto para o futuro.

O narrador onisciente distingue suas personagens pelos pronomes a mantê-las próximas ou distantes. Ele vê e sabe tudo, perscrutando consciências e sentimentos. No entanto, aceita a interlocução, que assegura movimento e dinamismo às ações. Sob essa ótica, a linguagem, em diferentes registos, concorre para o colorido dos relatos. E a erudição, anexando intertextos, combina semas e amplia significados. As pautas sociais determinam-se por cenários, indumentárias e adereços, ao modo como ostentação e singeleza alternam-se.

Seguindo passos, Mary confusa interroga-se "onde estou eu, onde estou eu, para quê, porquê, para quem". Mas, em terreno onírico, Elisa "vai por um grande descampado tão seco que a terra está branca"; e Elvira vê "um escobrejar de gavinhas, todas elas, a deitar corpo". Perturbada uma, esforçada outra, a terceira, maravilhada, sorve a vegetação. O sonho de Elvira exibe a uberdade: o solo prenhe de frutos.

Então, revolvendo a sonolência, a mulher ouve o seu homem que "ainda ronca de levezinho" e o menino que "geme, um bulir com a voz ainda miúdo". Compõe-se o quadro da maternidade e do amor: o menino amamentado ao seio, e o marido a pôr "de manso a mão no quadril e de manso a deixa ficar enquanto se desestremunha."

A "Epifania" refulge! Manifesta-se o sagrado na dignificação da família.

Elvira concentra e irradia a essência do ser mulher: gesta, nutre, cuida, acolhe, dedica- 
-se, ajuda, consola, ama. "Lacrimosa" transpõe sacrifícios na necessidade de habitar quarto alugado a senhoria exigente: "afazeres novos [...] um gesto e muitos ditos que não havia nas casas da mãe". Com o pai doente, Elvira sente que lhe coube "a recomposição de três gerações". Conforto é a fé do companheiro impelindo-a para ir "agora em aprendendos a ler", e ao filho dotará "uma enxada de prata para fender a noz do mundo". Prenúncio de evolução! E vem "Stella", a amiga com a notícia de nova morada. O "Atrium" inaugura-se com o "baptizo da casa" pelas águas da fertilidade. Elvira, "Pareces a cara da aurora lavada na nascente."

São momentos de devoção e agradecimento. A cada obra uma celebração!

Maria Velho da Costa oferece o melhor da Arte, desdobrando vidas, pulsando afetos, compondo o sublime.

\section{NOTAS}

* Universidade de Évora - Clepul - Centro de Literaturas e Culturas Lusófonas e Europeias da Faculdade de Letras da Universidade de Lisboa.

${ }^{1}$ Beatriz Weigert, "Um rito de passagem em Maria Velho da Costa", Da Galiza a Timor: A Lusofonia em Foco, Universidade de Santiago de Compostela, 2008, p. 1667.

${ }^{2}$ Alocução de Maria Velho da Costa à cerimónia de entrega do Prémio Camões 2002.

${ }^{3}$ O Lugar Comum, Lisboa, Morais, 1966, p. 7.

4 Maina Mendes, 3. ed., Prefácio de Eduardo Lourenço, Lisboa, Dom Quixote, 1993, p. 23.

${ }^{5}$ Lucialima, 3. ed., Lisboa, O Jornal, 1986, p.19.

${ }^{6}$ Casas Pardas, 3. ed. rev., Lisboa, Dom Quixote, 1986, p. 142.

${ }^{7}$ Casas Pardas, p. 101.

${ }^{8}$ Casas Pardas, p. 417.

${ }^{9}$ Irene ou o contrato social, Lisboa, Dom Quixote, 2002, p. 61.

${ }^{10}$ Myra, Lisboa, Assírio \& Alvim, 2008, p. 11.

${ }^{11} \mathrm{O}$ Lugar Comum, p. 77.

${ }^{12}$ Lucialima, p. 223.

${ }^{13}$ Casas Pardas, p. 93. 